\title{
Serum pyridoxal in patients with gastric pathology
}

\author{
C. R. SANDERSON AND R. E. DAVIS \\ From the Royal Perth Hospital, Perth, Western Australia
}

SUMMARY Fasting serum pyridoxal was assayed by an automated microbiological system in 60 patients investigated for dyspepsia, patients with active peptic ulceration being excluded from the study. Gastritis was present in 30 patients, gastric carcinoma in 16, six patients had benign polyps, and, in eight patients, radiology, endoscopy, and biopsy failed to show any abnormality. Of the 52 patients with gastric pathology, 44 had a low serum pyridoxal.

We have previously shown that active gastric ulceration is associated with a low serum pyridoxal (Sanderson and Davis, 1975), whereas patients with active duodenal ulceration had normal values and that this was unrelated to diet, alcohol intake, drug therapy, age or sex differences between the two groups. This present study was performed to investigate whether this abnormality was unique to peptic ulceration or if it occurred in other types of gastric pathology.

\section{Methods}

Blood was taken immediately before upper gastrointestinal endoscopy and the serum separated and stored at $-20^{\circ} \mathrm{C}$ until required for assay. Patients who in the month preceding endoscopy had either overt gastrointestinal bleeding or had received a blood transfusion were excluded from the study. Endoscopy was performed with the Olympus GIF Type D, and biopsies were taken in all cases via the endoscope. Serum folate was assayed by the method of Davis et al. (1970) using Lactobacillus casei as the test organism (reference range 2:5-18.3 ug/l). Serum $B_{12}$ by the method of Nicholas and Pitney (1958) using Euglena gracilis as the test organism (reference range $160-850 \mathrm{ng} / 1)$, and pyridoxal by the method of Davis et al. (1973) using $L$. casei as the test organism. The laboratory was unaware of the endoscopic or histological diagnosis until the end of the study.

Sixteen patients had gastric carcinomas, six had benign polyps, nine had superficial gastritis, 19 had atrophic gastritis, and gastric atrophy was

Address for correspondence: Dr C. R. Sanderson, Gastroenterology Unit, Royal Perth Hospital, Wellington Street, Perth, Western Austrailia.

Received for publication 3 February 1976 present in two patients. A further eight control patients were investigated for dyspepsia, and both radiology and endoscopy plus biopsy failed to show any abnormality.

\section{Results}

A total of 60 patients (25 males and 35 females) were investigated. Their ages ranged between 41 and 89 years with a mean of 64 years. Serum folate was below normal in 13 and serum pyridoxal below normal in 44 patients, and vitamin levels in individual patients are shown in Fig. 1.

Serum pyridoxal normally decreases with age and is slightly lower in females than males (Hamfelt, 1964; Anderson et al., 1970) and individual results are shown in Fig. 2 (males) and Fig. 3 (females).

Serum $B_{12}$ was raised in two cases: $1250 \mathrm{ng} / \mathrm{l}$ and $1400 \mathrm{ng} / \mathrm{l}$, and below normal in none. Two patients with pernicious anaemia were receiving vitamin $B_{12}$ at the time of this study.

Of the eight patients in whom no abnormality was found, serum folate was normal in all eight and one patient had a low serum pyridoxal. Individual pyridoxal values found in the various types of gastric pathology are shown in Fig. 4, and the results for those patients in whom no abnormality was found are shown in the normal column.

\section{Discussion}

Dietary insufficiency, malabsorption, increased utilization or excretion, or any combination of these factors, could be responsible for the low serum pyridoxal found in the majority of patients with gastric pathology.

Anorexia and a consequent poor diet frequently 


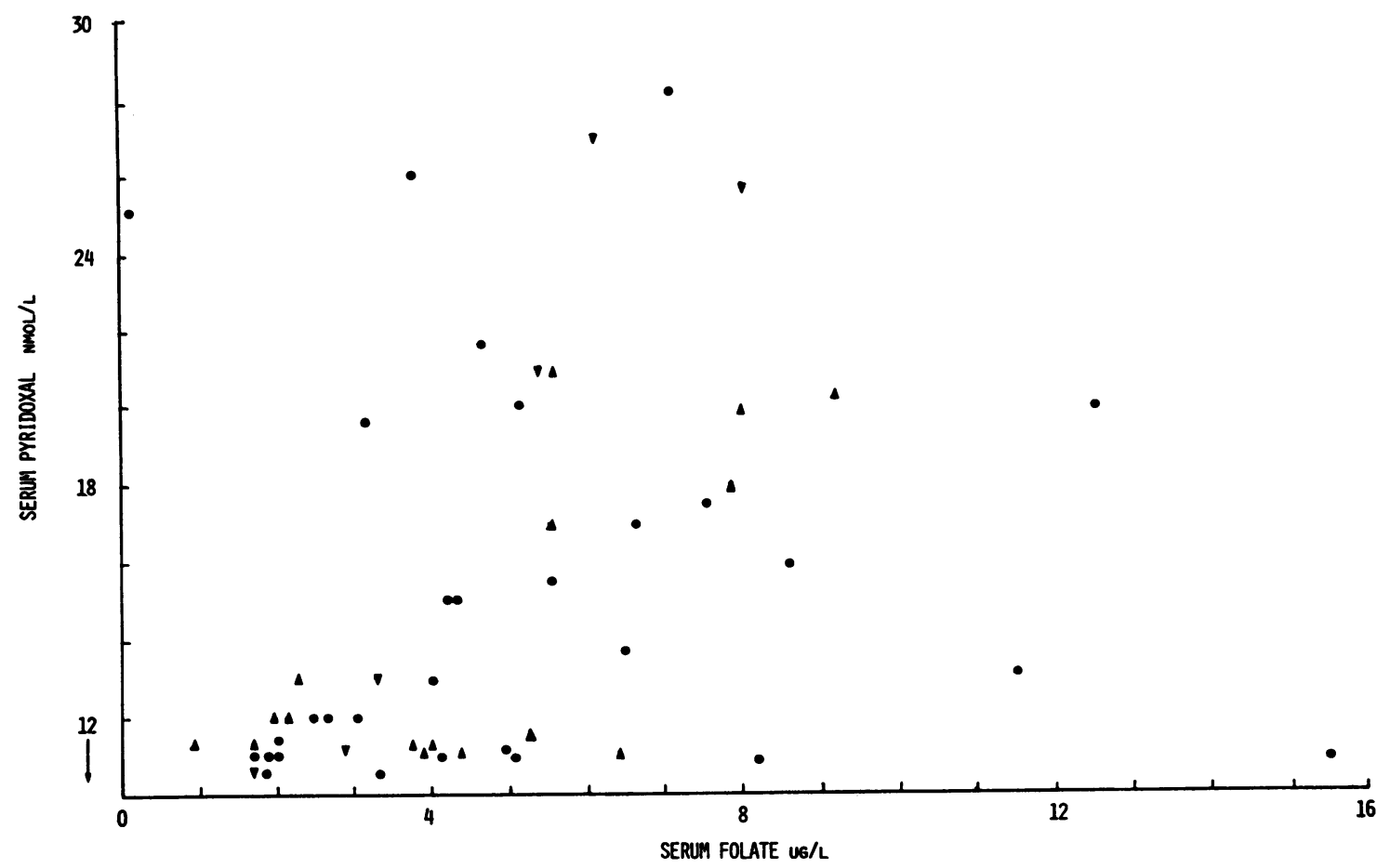

Fig. 1 Serum pyridoxal/serum folate in indvidual patients. @ Gastritis. $\triangle$ Carcinoma. $\mathbf{\nabla}$ Polyp.

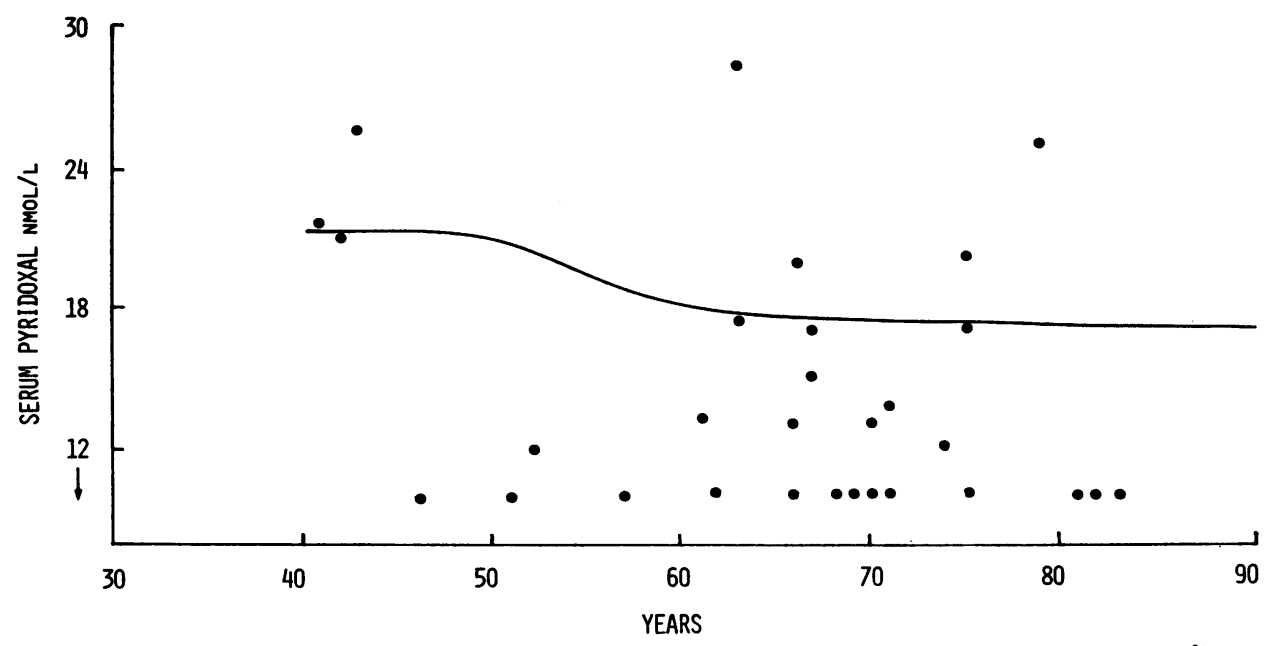

Fig. 2 Serum pyridoxal/age in males. The lower limit of the normal range is shown as a continuous line.

accompany gastric pathology and dietary insufficiency may be the cause of a low serum pyridoxal found in our patients. An associated deficiency in folate might be expected to accompany such an abnormality and, of 13 patients with a folate below $2.5 \mathrm{ug} / \mathrm{l}, 12 \mathrm{had}$ a serum pyridoxal of 12 or less.
However, in the 26 patients with a serum pyridoxa of this order, serum folate varied between 0.9 $\mathrm{ug} / \mathrm{l}$ and $15.5 \mathrm{ug} / \mathrm{l}$. No significant difference $(\mathrm{P}>$ 0.05 ) was found between the serum folate values of the gastritis and carcinoma groups, although weight loss of greater than $3 \mathbf{~ k g}$ in the preceding three 


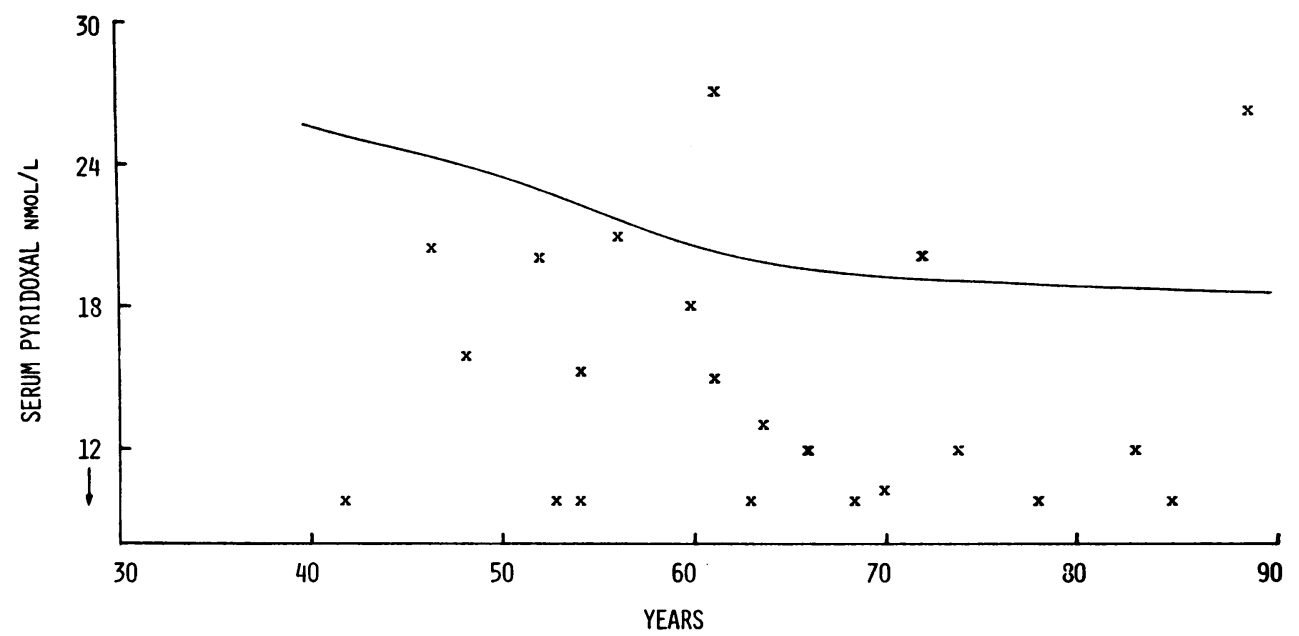

Fig. 3 Serum pyridoxallage in females. The lower limit of the normal range is shown as a continuous line.

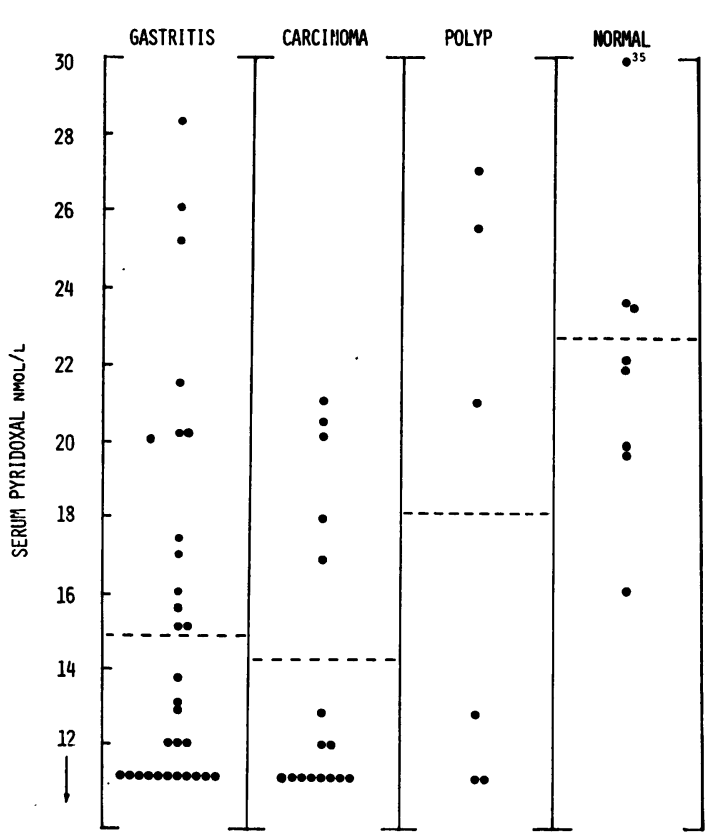

Fig. 4 Individual serum pyridoxals in pathological groups. The mean values for each group are shown as an interrupted line. (Because we are unable accurately to assay values below $12 \mathrm{nmol} / \mathrm{l}$, values below this figure are assumed to be $11 \mathrm{nmol} / \mathrm{l}$ for the purpose of this comparison.)

months was common in the latter group and infrequent in the former, as far as could be ascertained by reference to previous hospital attendances or historically when no record was available. This group of patients is obviously highly selected as all were referred for endoscopy because of clinical suspicion of gastric pathology, whether or not this was confirmed by radiology, but, in those eight patients who were radiologically, endoscopically, and histologically normal, only one had a low serum pyridoxal, and we were unable to ascertain that the dietary habits of this group varied markedly from those patients in whom gastric pathology was found.

Animal experiments (Booth and Brain, 1962) have shown that no significant absorption of pyridoxine occurs from the stomach and that the jejunum is the site of absorption of this form of vitamin B6. There is also strong circumstantial evidence available (Morris et al., 1970) to show that the jejunum is the main site of vitamin B6 absorption in man. None of our patients is known to suffer from small bowel disease, although no studies of small bowel function were performed.

Surveys of alcoholic patients (Hines and Grasso, 1970; Davis and Smith, 1974; Lumeng and Li, 1974) have shown that about half have low serum pyridoxals, but only two of our patients admitted to a regular large intake of alcohol. No patient was receiving anticonvulsant therapy, L-dopa, isoniazid, or penicillamine, drugs previously reported (Biehl and Vilter, 1954; Hagberg et al., 1966; Hollister et al., 1966; Evered, 1971) to be associated with abnormalities of vitamin B6 metabolism, and we have previously shown that our premedication of pethidine and atropine does not effect fasting serum pyridoxal levels (Sanderson and Davis, 1975).

We have recently investigated a patient who, in 1974, was one of the controls used in the establish- 
ment of a normal range of serum pyridoxal in this hospital and the serum $B_{12}$, folate, and pyridoxal were within the normal range (serum $B_{12} 335 \mathrm{ng} / 1$; serum folate $10 \cdot 2 \mathrm{ug} / 1$; serum pyridoxal $49 \cdot 8 \mathrm{nmol} / \mathrm{l}$ ). Six months after these results were obtained, she complained of episodes of epigastric discomfort and a barium meal was strongly suggestive of an antral ulcer. This was confirmed at endoscopy and biopsy and cytology showed the lesion to be benign. Vitamin assays were repeated at endoscopy and serum $B_{12}$ and folate were still within the normal range $\left(B_{12} 250 \mathrm{ng} / \mathrm{l}\right.$; folate $\left.8 \cdot 1 \mathrm{ug} / \mathrm{l}\right)$, but the serum pyridoxal had now fallen to below normal (16 nmol/l). This patient is unique in our experience and it is improbable that we will have further cases in our control population; however, it does suggest that the development of gastric ulceration is accompanied by a fall in serum pyridoxal to below normal values.

This present report shows that a low serum pyridoxal is not restricted to patients with active gastric ulceration but occurs with other common forms of gastric pathology. Further study of absorption and excretion of vitamin B6 in patients with gastric pathology appears to be indicated before relevant conclusions can be drawn regarding this particular association.

We should like to acknowledge the assistance received from Dr T. E. Waters, Dr R. Finlay-Jones, Dr L. Matz, Dr E. Waters, Dr R. Warren, Mr J. Moulton, and Miss C. Coleman in the preparation of this paper.

References

Anderson, B. B., Peart, M. B., and Fulford-Jones, C. E.
(1970). The measurement of serum pyridoxal by a microbiological assay using Lactobacillus casei. Journal of Clinical Pathology, 23, 232-242.

Biehl, J. P., and Vilter, R. W. (1954). Effect of isoniazid in vitamin B6 metabolism: its possible significance in producing isoniazid neuritis. Proceedings of the Society for Experimental Biology, 85, 389-392.

Booth, C. C, and Brain, M. C. (1962). The absorption of tritium-labelled pyridoxine hydrochloride in the rat. Journal of Physiology, 164, 282-294.

Davis, R. E., Nicol, D. J., and Kelly, A. (1970). An automated method for the measurement of folate activity. Journal of Clinical Pathology, 23, 47-53.

Davis, R. E., and Smith, B. K. (1974). Pyridoxal and folate deficiency in alcoholics. Medical Journal of Australia, 2, 357-360.

Davis, R. E., Smith, B. K., and Curnow, D. H. (1973). An automated method for microbiological assay of serum pyridoxal. Journal of Clinical Pathology, 26, 871-874.

Evered, D. F. (1971). L-dopa as a vitamin-B6 antagonist. (Letter.) Lancet, 1, 914.

Hagberg, B., Hamfelt, A., and Hansson, O. (1966). Tryptophan load tests and pyridoxal-5-phosphate levels in epileptic children. Acta Paediatrica Scandinavica, 55, 371-384.

Hamfelt, A. (1964). Age variation of vitamin B6 metabolism in man. Clinica Chimica Acta, 10, 48-54.

Hines, J. D., and Grasso, J. A. (1970). The sideroblastic anemias. Seminars in Hematology, 7, 86-106.

Hollister, L. E., Moore, F. F., Forrest, F., and Bennett, J. L. (1966). Antipyridoxine effect of D-penicillamine in schizophrenic men. American Journal of Clinical Nutrition, 19, 307-312.

Lumeng, L., and Li, T-K. (1974). Vitamin B6 metabolism in chronic alcoholic abuse. Journal of Clinical Investigation, 53, 693-704.

Morris, J. S., Ajdukiewicz, A. B., and Read, A. E. (1970). Neurological disorders and adult coeliac disease. Gut, 11, 549-554.

Nicholas, D. R., and Pitney, W. R. (1958). Microbiological assay of vitamin $B 12$ content of serum using Euglena gracilis. Australian Journal of Experimental Biological and Medical Science, 36, 603-608.

Sanderson, C. R., and Davis, R. E. (1975). Serum pyridoxal in active peptic ulceration. Gut, 16, 177-180. 